\title{
Urinals for water savings and nutrient recovery: a feasibility study
}

\author{
TL Chipako ${ }^{1}$ and DG Randall** \\ 'Civil Engineering Department, University of Cape Town, 7700 Cape Town, South Africa
}

\begin{abstract}
This research investigates the feasibility of implementing waterless urinals at a public university in Cape Town, South Africa. Two analytical approaches were adopted to assess the feasibility of the proposed systems: a social study in the form of an online survey and an economic evaluation of four separate water savings and nutrient removal systems. In terms of the online survey, $87 \%$ of respondents claimed they would use urine- diverting technology and $79 \%$ stated they would eat food that was grown using urine-recycled phosphorus as fertilizer. It was found that merely reducing the number of times a urinal could be flushed to 3 times per day could save approximately $18 \mathrm{ML}$ of water annually. Additionally, the University of Cape Town requires $3600 \mathrm{~kg}$ of fertilizer for its sports fields, while the urine collected in waterless systems has the potential to produce $6700 \mathrm{~kg}$ of fertilizer. This work has shown that a significant amount of water can be saved by installing waterless urinals in public institutions such as a university. It also shows that there is potential to recover valuable resources from our 'waste' streams, thus closing various nutrient cycles through on-site fertilizer production.
\end{abstract}

Keywords: fertilizer, nutrient recovery, phosphorus, urine, water savings

\section{INTRODUCTION}

Human waste can be broken down into two main categories: faeces and urine. When separated, these streams have desirable concentrations of nitrogen, potassium and phosphorus (Andersson et al., 2016). Human faeces have been identified as a resource which can positively affect industrial and agricultural sectors. It is currently estimated that, as of 2015, close to 9.5 million $\mathrm{m}^{3} / \mathrm{d}$ of faeces is produced globally (Andersson et al., 2016). It is estimated that this amount can replace $25 \%$ of the nitrogen and $15 \%$ of the phosphorus that is utilized for worldwide synthetic fertilizer production (Andersson et al., 2016). Moreover, recovery of nutrients on a large scale holds potential for financial gain, as nutrients can be used to produce fertilizers which can be sold for a profit.

Likewise, resource recovery from urine is of great importance (Randall and Naidoo, 2018). Phosphorus, which exists within urine, is a nutrient which is important for all forms of life. It has a variety of uses pertaining to the production of fertilizers and detergents (Barbosa et al., 2016). The primary sources of phosphorus in the world are phosphate rocks, which are being depleted at a rapid rate due to increased demand as a result of population growth (Cordell et al., 2009). Wastewater mismanagement and the release of phosphorus into water bodies is the primary reason for environmental degradation such as eutrophication (Udert, 2018).

Urine accounts for less than $1 \%$ of wastewater content by volume; however, it accounts for over $80 \%$ and $50 \%$ of the nitrogen and phosphorus, respectively (Wilsenach and Van Loosdrecht, 2003). Nitrogen is viewed as an unwanted nutrient in wastewater. The presence of nitrogen and phosphorus in water can promote eutrophication (growth of algae), which can cause deoxygenation due to the growth of autotrophs and increased toxicity from the death of aquatic organisms (Chislock et al., 2013). Decreasing the volume of these nutrients

\footnotetext{
To whom all correspondence should be addressed.

e-mail: dyllon.randall@uct.ac.za
}

Received 11 July 2018, accepted in revised form 4 April 2019. in wastewater could potentially improve the effluent quality from wastewater treatment plants (WWTPs) and conserve energy in the biological nutrient removal processes (Wilsenach and Van Loosdrecht, 2003).

Additionally, it is not uncommon for struvite to precipitate spontaneously in the piping systems of municipal treatment plants. This causes additional operation and maintenance costs as this decreases system efficiency and requires frequent cleaning (Barbosa et al., 2016). Removing a large portion of phosphorus in these wastewater streams would decrease these issues.

Conservation of water is important for many reasons. Decreasing monetary expenditure and the influent load at water treatment works are among those reasons (Munch and Winker, 2011). Water-saving techniques and technologies have become a major point of interest globally. Comparatively, conventional urinals and flush toilets typically use between 4 and $8 \mathrm{~L}$ of water per flush, respectively, whereas waterless urinals and source-separating toilets use zero and $2 \mathrm{~L}$ of water per flush, respectively (Munch and Winker, 2011).

Cape Town is currently experiencing severe water shortages because of insufficient measures being taken to cope with population growth over a 23 -year period (Bohatch, 2017). The population has increased by over $55 \%$ between 1995 and 2018, whereas the dam storage capacities have only increased by $15 \%$ (Bohatch, 2017).This shortage has drastically changed the mindsets of residents with regards to their views on water, as is evident by the significant water savings adopted by many Capetonians. In the past, areas such as Australia and California have experienced droughts due to varying reasons in 2003 to 2007 (Boughton, 2009), and 2012 to 2014 (Williams et al., 2015), respectively. The drought in Australia was caused by variable weather conditions which led to long spells of dry conditions (Boughton, 2009), while the California drought was due to weather patterns which saw a ridge of high atmospheric pressure preventing winter storms from reaching the city (Williams et al., 2015). Each area used different methods to attempt to alleviate water shortages. In Australia, water restrictions were put in place which saw residents of South East Queensland decrease their water usage from 300 L to $129 \mathrm{~L}$ per person per day (Olivier, 2017). Residents of California attempted to decrease potable water usage by using 
greywater, water from sinks, bathtubs and washing machines (not from toilets), to flush toilets and for irrigation purposes (Sharvell, 2016).

Alternatively, it has been proposed that coastal areas should investigate using seawater to provide water for flushing toilets (Dai et al., 2014). Since 1958, over $80 \%$ of the residents within Hong Kong have been using seawater to flush their toilets. This has reportedly resulted in potable water savings of over 22\% per annum (Dai et al., 2014). This system does have its shortcomings though. The implementation of dual water systems (fresh water for potable demands and sea water for flushing demands) comes at potentially large infrastructure costs (Smith et al., 1996). Corrosion in pipes due to increased presence of hydrogen sulphide can lead to large costs in maintenance and repair (Smith et al., 1996). This is avoidable if appropriate piping material is used and it is generally advisable that buildings utilizing these dual systems must be greenfield projects (new buildings) and not retrofitted installations (Smith et al., 1996).

Waterless urinals could be used to collect nutrients and save water, especially considering that urine consists of approximately $95 \%$ water (Chariar and Sakthivel, 2009) and thus does not require a source of water to flow into drainage pipes. The urinal design is simple and does not differ in appearance and user functionality to conventional flush urinals for males. The main difference between the two systems lies in where the urine flows towards once it enters the primary drainage pipes. In conventional water-based systems, urine and faeces combine and enter the sewage system as black water, where they are transported to a WWTP to be treated (Wilsenach and Van Loosdrecht, 2003). No resource recovery takes place in this scenario. Conversely, in waterless systems, urine is drained into storage containers and is reworked during treatment to be recycled for agricultural purposes (Von Münch and Dahm, 2009).

One issue which works towards the detriment of the implementation of a waterless system is public perception that waterless technologies produce overwhelming odours (Munch and Winker, 2011). Despite this, elegant solutions to this problem have been engineered. There are many methods that can be used to control this, namely sealant liquid traps, membrane traps and biological blocks (Chariar and Sakthivel, 2009). Other ways of preventing odour include stabilizing urine. Urea hydrolysis is the process by which carbon dioxide and free volatile ammonia are formed from urea (Randall et al., 2016). Pungent odours are expelled as a result of the urea hydrolysis process (Zhang et al., 2013). Therefore, preventing urea hydrolysis is desirable. Urea stabilization can be achieved by adding one or more of a selection of acids/bases to urine, electrochemical treatment, or inhibiting effects of urease (the main catalyst for urea hydrolysis) (Randall et al., 2016). Calcium hydroxide can be dosed to urine collected directly from urinals (from storage tanks or containers) to prevent urea hydrolysis. This process is also beneficial as it maximizes the recoverable nutrients from urine. It has been shown to be an effective method for producing calcium phosphate on-site, within novel nutrient recovery urinals (Flanagan and Randall, 2018), and the urine-derived fertilizers are just as effective as conventional fertilizers (Meyer et al., 2018).

This work aims to evaluate the feasibility of installing waterless urinals for nutrient recovery at a public university in Cape Town, South Africa. It also evaluates the user's acceptance of such devices as well as their willingness to eat food grown from urine-derived fertilizers.

\section{MATERIALS AND METHODS}

The evaluation focused on two different aspects: an online survey and an economical evaluation of four urinal systems.

\section{Online survey}

The online survey was made with the intention of assessing certain unknowns regarding waterless technologies. Assessing whether the public would accept waterless technologies was deemed important. Additionally, the survey aimed to spread awareness among the participants regarding the depletion of natural phosphate reserves as well as the water-saving potential of waterless urinals. The survey was distributed to approximately 16500 individuals within the university, comprising of both students and staff members.

Although this investigation deals with the installation of these systems on the Upper Campus of the University of Cape Town (UCT), this survey was distributed to all UCT personnel, regardless of which campus they were situated on. UCT staff and students were both included in the survey. The survey was designed using the Google Forms Survey software. It consisted of 14 questions in total (see Table A1, Appendix). The survey began with a brief overview of the project, outlining what waterless urinals and source-separating toilets are, as well as why phosphorus recovery is important. After consenting to participate, the respondent was then asked to provide their faculty, age bracket, gender and whether they are a student or staff member.

Participants were then asked if they would be willing to use a waterless urinal or source-separating toilet themselves. Following this, it was then asked if one would be willing to use these technologies, knowing it could conserve water. This question was posed to assess if water conservation was a main priority to participants. Subsequently, the respondents were asked if they would eat food that was grown using fertilizer which contained phosphorus recycled from urine. The survey concluded by asking the participant why they would not eat food grown in this manner, if they specified they would not. In addition, both male and female respondents were included in the survey since unisex urinals do exist and thus urine can be collected from both male and female donors. Questions around maintenance and cleanliness of the urinals were not included because the urinals on campus are currently well maintained and kept clean by full-time cleaning staff.

Students and staff were contacted to participate in the survey through emails sent by way of mailing lists controlled by Deans of each faculty as well as the UCT Department of Student Affairs. Survey responses were downloaded from Google Documents once 500 participants had responded to the survey.

A chi-square test was conducted on the answers to the survey to assess if there were any statistically significant differences in the answers given. In each case, a null hypothesis $\left(H_{0}\right)$, stating that there was no difference in the answers between each group was made. For this null hypothesis, it was assumed that the answers to each question were evenly distributed, based on the quantity of respondents per group. Conversely, the alternate hypotheses stated there was a significant difference in the answers recorded. Details of this analysis are given in Table A4 in the Appendix.

The chi-square test assessed if there was a statistically significant difference in: 
- Males and females who were willing to use urine diverting technology (UDT) and who were not

- Engineering and Built Environment (EBE) faculty and Humanities faculty students who were willing to use UDT and who were not

- Males and females who are willing to eat food grown from urine derived fertilizer and who are not

- EBE and Humanities students who were willing to eat food grown from urine derived fertilizer or not

- Males and females who were willing to use unisex urinals or not

- Faith in the ability of the public to maintain a new urinal system by staff and students

\section{Economic evaluation}

Four separate urinal systems were investigated and directly compared to one another. The main objectives were to compare the operating costs, capital costs and cost recovery for each system to ascertain which system is most applicable. As this was primarily a monetary-based evaluation, aspects such as environmental impact, other than in the case of water conservation and nutrient recovery, were not considered. This investigation only focused on waterless urinals. Including source-separating toilets was deemed to be too large of an investment to incorporate simultaneously with the installation of waterless urinals. For this study, only current urinal users, i.e., male urine donors, were considered for ease of comparison and calculation. However, it is important to note that unisex urinals could also be used to increase the collection volume of urine.

Currently there are approximately 800 and 260 toilets and urinal units located on the Upper Campus section of the university, respectively. The following design cases were considered:

\section{Case 1: Business-as-usual}

In this scenario, the current, water-based system is left unchanged. This is done to evaluate whether it is advisable or not to overhaul the system. This system does not entail recovery of resources as all waste is directed to conventional sewage systems.

\section{Case 2: Level 5 water restrictions are enforced}

As of 1 February 2018, the City of Cape Town enforced Level 6b water restrictions. This was introduced with the primary objective of decreasing the water used by the city to $450 \mathrm{ML}$ per day. This translates to $50 \mathrm{~L}$ per person per day, or roughly 3 flushes per day per toilet. This case investigates the potential costs and saving that could occur if a ' 3 flushes per urinal' rule was enforced for all urinals on Upper Campus. All flush buttons would need to be removed from urinals and a timer flush device attached. These devices would flush each toilet exactly 3 times per day.

\section{Case 3: Installation and maintenance of the urinal system by an external organization}

Installation and maintenance of new systems could prove to be difficult. Case 3 investigates how enlisting an external organisation to install and maintain a waterless urinal system at UCT would compare to the other proposed cases. This case is based on the hypothetical appointment of a urine treatment company to provide this service at UCT. It is assumed that the urine treatment plant for fertilizer production is already installed and hence there is no capital expenditure for this case.

\section{Case 4: Installation and maintenance of the waterless urinal system by UCT}

In this scenario, UCT will install the waterless urinal systems and treat the urine to produce fertilizers. This will be done internally, without the use of an external service provider. This case considers not only the urinal system, but additionally, the treatment plant which is required to be built to treat the urine. A detailed assessment of the capital and operational costs of this treatment plant was not conducted. Instead, rough estimates were deduced based on work conducted by Sikosana et al. (2016) detailing the potential of nutrient recovery in South Africa. Note that in Cases 3 and 4, fertilizer is produced in the form of struvite crystals. Table A2 (Appendix) details a summary of the assumptions which formed the basis of the design criteria for each urinal system.

Males formed the hypothetical user base of the system in question, as retrofitting the existing urinal infrastructure is presumed to be significantly more feasible than installing new units altogether (in male and female facilities). Moreover, each case was assessed assuming all flow pipes do not allow for losses of urine or water through friction or scaling. All liquid material was assumed to transfer to either the sewer system or the treatment plant. Table A3 details a summary of the monetary assumptions which formed the basis of the design criteria for each urinal system.

It is important to note that the input data which form the design assumptions are likely overly conservative. Criteria such as the number of flushes per urinal per day assumed that each student urinates 5 times a day (Rossi et al., 2009), twice at home (upon waking up and before falling asleep) and 3 times on campus. Each separate usage of a urinal is assumed to result in a subsequent flush. Only toilet visits which occur on campus were considered when modelling each scenario. Additionally, each urinal was assumed to be cleaned once a day with $20 \mathrm{~mL}$ of cleaning bleach. To make the number of flushes per day more realistic, a factor of 0.8 was applied since not all users flush the urinal after use.

An equal split of students per faculty was assumed, based on the total number of students attending UCT as of 2017. Moreover, UCT is split into many different campuses, with each faculty being allocated to a specific campus. Three of these faculties are known to be fully based on Upper Campus (Engineering and Built Environment, Commerce, and Science). The remaining faculties, however, are known to occasionally have lectures on Upper Campus. Due to a lack of accurate data on how frequently this occurs, only students who are permanently situated on Upper Campus were considered.

It was assumed that during the semester all students and staff will be present on campus, whereas during holidays only staff are present on campus. The operating and capital costs, as well as the cost recovery values in each case, comprise of the following aspects:

- Case 1: Operating costs were evaluated based on staff salary, cleaning products and water and sanitation costs. Capital costs and cost recovery were not applicable.

- Case 2: Operating costs were evaluated in the same manner as Case 1. Capital costs were evaluated by summing the cost of timer flush systems for each urinal on Upper Campus. Cost recovery did not apply to this case.

- Case 3: A private urine treatment company offers an allencompassing service which waives the installation costs of retrofitting the conventional system and charges 11.72 USD per urinal per month. Since installation fees do not apply, and it is assumed that the external company has already constructed a 
nutrient recovery facility, capital costs are not applicable. Cost recovery is not applicable as the private company treats and distributes the urine-based fertilizer themselves.

- Case 4: Operating costs were evaluated based on staff salary, cleaning products, the cost of magnesium to treat urine (to produce struvite) and the operating cost of the treatment plant which must also be built. The capital cost comprises of the cost of building the treatment plant and the cost of retrofitting the buildings on campus to waterless urinals. Cost recovery is based on the money gained from selling the treated urine as a fertilizer as well as the money saved by UCT as a result of producing fertilizer itself and not having to buy it.

All costs were evaluated on a yearly basis, except for capital cost, which would be a once-off expense for the duration of the evaluation period. It was assumed, for the purposes of the economic models, that cleaning and maintenance costs are the same for water-based urinals and waterless urinals.

\section{RESULTS AND DISCUSSION}

\section{Survey data analysis}

Upon collation of the survey data, it was found that the only major difference in the answers given between the different classification groups were between gender and faculty. It is worth noting that according to the findings of Fielding and Roiko (2014), the provision of a summary of what the system entailed as well as the reasons why we would want to recover phosphorus, likely increased levels of support for the system - as seen in the responses. It is difficult to quantify the extent to which this provision of initial information affected the respondent's answers.

\section{Survey sample analysis}

There were 500 responses, which represents a response rate of roughly $3.1 \%$. All responses were deemed to be valid as a Google login and consent confirmation was required to be eligible to participate in the study. Furthermore, each question required an answer in order to submit the final form.

The majority of the survey participants (69\%) stated that they had never heard of urine-diverting technologies such as waterless urinals and source-separating toilets. Similarly, a survey distributed in the University of Hawaii in 2014 (Lamichhane and Babcock, 2013) indicated that $80 \%$ of respondents had never heard of the urine-diverting technologies before completing the survey.

\section{Acceptance of system}

High levels of support were reported, with $87 \%$ of respondents stating they would be willing to use either a source-separating toilet or a waterless urinal. There was no statistical difference between males and females as well as the EBE Faculty and Humanities Faculty. When asked if one would use these technologies, prefaced with the notion that it could save water, $96 \%$ of participants were in favour of using the proposed systems. Considering the water shortage in Cape Town, at the time which this research was undertaken, this is not a surprising statistic as residents are generally aware of the need to save water. It is an important finding, nonetheless. This gives tangible evidence that the notion of water conservation is a main priority for those who contributed to the survey data.
However, despite this, when asked whether one would be willing to use unisex urinals, while still prefaced with the notion that it would save water, only $64 \%$ of participants were in support of this idea. It was found that $81 \%$ of males were in favour of using unisex waterless urinals, while only $49 \%$ of females felt similarly. Based on literature, female urinals historically do not have high levels of acceptance, water based or not (Chariar and Sakthivel, 2009). This is due to the seemingly unnatural squat position females need to take. From initial results, it appears the focus of urine-diverting technologies with regards to females must be placed on sourceseparating toilets or an education campaign needs to be implemented that specifically addresses these issues. While not waterless urinals, no-mix toilets that also separate urine were accepted by $80 \%$ of users in 7 Northern and Central European countries (Lienert and Larsen, 2010).

The EBE and Humanities faculties consisted of the two largest response groups within the survey, as they made up 29\% and $42 \%$ of the total respondents, respectively. It was found that EBE students shared a higher acceptance level for the proposed system than Humanities students, showing $83 \%$ and $74 \%$ acceptance, respectively. These results should be treated with caution since university students might be more prone to care about such issues and perhaps they are more open-minded.

\section{Factors influencing user willingness to use urine- diverting systems}

Among the $13 \%$ of individuals who indicated that they were unwilling to use the proposed technologies, $64 \%$ of respondents claimed that it was due to concerns pertaining to the sanitation of the urine-diverting systems in question. A breakdown of the most common reasons for being unwilling to use the system can be seen in Fig. 1A.

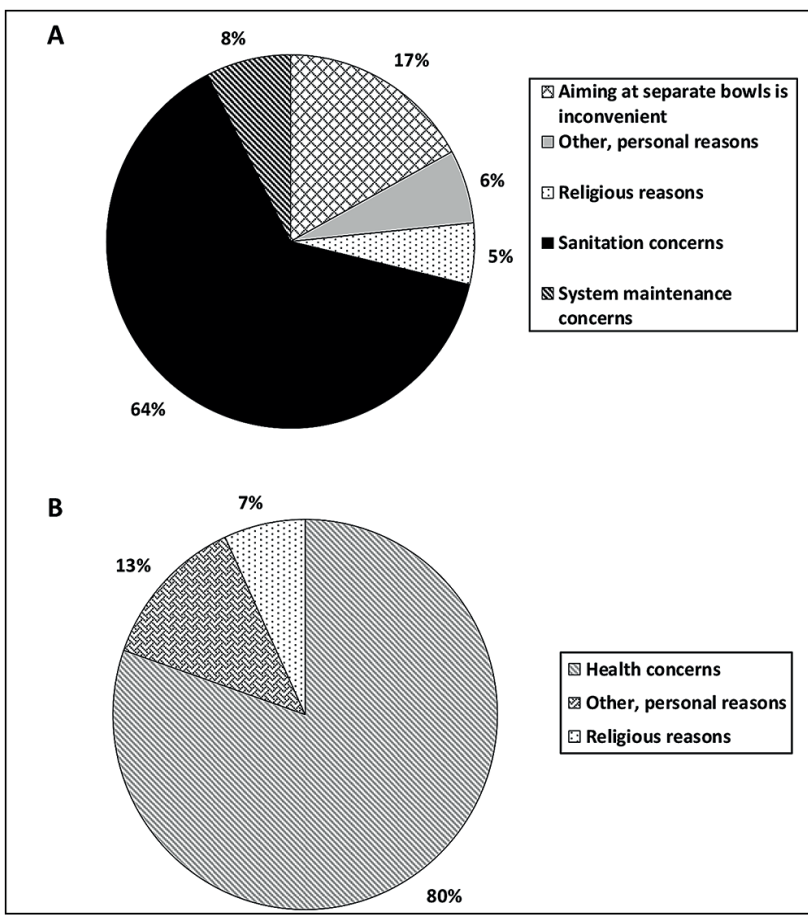

Figure 1

A: Representation of reasons causing aversion to urine diverting technologies at UCT. B: Reasons against eating food grown using urinerecycled phosphorus. 
When analysing the difference between genders, the second-largest factor causing scepticism regarding the sourceseparating toilets was also recorded. Among females, 21\% were against the idea of having to aim at separate bowls when using the toilet. Among males, $13 \%$ had issues pertaining to the maintenance and longevity of the system. Although males and females who are unwilling to use the technology represent a minority of the sample population (13\%), the concerns raised in the survey may prove to be influential upon physical implementation of any future urine-diverting technologies at UCT. This becomes more apparent when considering this survey likely served as an introduction to urine separation to approximately $69 \%$ of respondents.

Another factor which may hinder the development of any future projects is the trust the user base has regarding source-separating toilets. In total, $61 \%$ of participants claimed that they did not believe that the system would be properly maintained in a university environment. In order to establish trust within any system, several factors regarding maintenance and societal perception are required to be addressed. Previous studies have indicated that mismanagement of waterless urinals by users, and insufficient maintenance efforts by staff, are likely to cause low levels of satisfaction with urinal systems (Blume and Winker, 2011). To combat this, cleaning staff must be sufficiently educated to maintain waterless urinals and users must be informed of the potential benefits pertaining to a waterless system.

Most respondents (81\%) claimed they had no previous knowledge of the depleting global phosphorus levels. Additionally, $79 \%$ of individuals claimed they would be willing to eat food that was produced using fertilizer that utilised urine-recycled phosphorus. There were statistical differences in the answers given by members of the EBE and Humanities faculty pertaining to their willingness to eat food grown using urine-derived fertilizer. EBE students were more willing to accept the proposal and generally males were more willing to accept this notion. As seen in Fig. 1B, the main reason, among those who were not willing to eat this food, was health concerns pertaining to the consumption of this food. These likely stem from the taboo which surrounds human waste. Work conducted by Andersson (2015) claims that farmers in Uganda believe 'urine (is) seen as dirty. If you want to use it, you are not seen as normal.' These social aspects would have to be addressed if urine was indeed to be used to grow food for human consumption. This aversion is not unfounded, however. Certain contaminants have been known to persist within urine upon treatment. These include pharmaceuticals (Lienert et al., 2007) and pathogens.

With regards to the chi-square tests conducted, significant differences in the answers given by members of the EBE and Humanities faculties were recorded, pertaining to willingness to eat food grown using urine-derived fertilizer. EBE students were more willing to accept the proposed notion in each case, as evidenced through their higher acceptance in the survey. Similarly, a significant difference was found regarding the willingness of males and females to eat food grown using urine-derived fertilizer and use unisex urinals. Proportionally, males were more accepting of both parameters, when compared to females. Interestingly, it was found that there was a significant difference in the belief that a new urinal system would be properly maintained, between staff and students. More staff than students stated that they believed the user base of any new technology would use it appropriately.
Source-separated urine from toilets runs the risk of being cross-contaminated with faeces. As a result of this, the sanitation of all collected urine (from urinals and sourceseparating toilets) is compromised (Etter et al., 2015) as it all collects to the same location. Methods of inactivating pathogens from urine are common practice and include urine storage, heating of struvite to decrease moisture content, nitrification and distillation (Etter, Udert and Gounden, 2015). Similarly, pharmaceuticals pose a potential threat to human health if not removed from urine. Most nutrients and pharmaceuticals (such as antibiotics and antidepressants) leave the human body through urine (Shraim et al., 2017). Additionally, a high occurrence of HIV in South Africa leads to a large amount of antiretroviral drugs being present within wastewater effluents (Etter et al., 2015). Most pharmaceuticals are not removed upon leaving WWTPs, so they are left to flow into natural ecosystems (Shraim et al., 2017). This can have negative effects on aquatic life and communities which reuse treated wastewater for domestic purposes. Studies have shown that pharmaceutical can be absorbed by plants. How they affect these plants is unknown. Furthermore, how this would affect plants grown with fertilizers that contain pharmaceuticals is also unknown (Etter et al., 2015). As a precaution, treatment techniques such as nitrification and the addition of powdered activated carbon (PAC) are done to remove pharmaceuticals from urine. PAC removes pharmaceuticals by absorbing them, with the added benefit of not removing useful nutrients and not leaving any by-products, which would need to be considered in any other process (Etter et al., 2015).

\section{Survey data discussion}

The results of the survey indicate that there is an inherent lack of knowledge when it comes to urine-diverting technologies as well as resource recovery of phosphorus. Previous studies pertaining to climate change indicate that one's attitude towards the environment is based on many factors, such as the benefits and consequences they expect to receive, their personal emotions with regards to the situation and the social influences they experience (Patchen, 2006).

The survey results indicate that water conservation is an important concept amongst the sample population, with $96 \%$ claiming they would use these technologies on the condition that it saves water. Appealing to this and outlining the proposed system as a benefit is important. In addition, highlighting the consequences of non-compliance is equally important. Currently the City of Cape Town is trying to encourage the public to decrease their water consumption through a multitude of campaign posters, distributed through social media. This is likely being done with the intention of evoking an emotive response within the public that could lead to increased water conservation efforts. Many believe that people are more likely to put efforts towards mitigating a problem when the method required to alleviate the situation on their part is realistic (Patchen, 2006).

Social influence plays a large role in influencing behaviour. For example, someone living in a home with separate garbage bins for glass, paper and metal is more likely to recycle those than one who does not (Patchen, 2006). Communities which facilitate water conservation are more likely to conserve water. Likewise, with regards to phosphorus recovery, showing people the consequences of not preparing for global phosphorus depletion and how their actions could lead to phosphorus 
recovery, could appeal to the intended population. Men would not have to change their bathroom routines to adjust to the new system (Von Münch and Dahm, 2009). There is an inherent divide amongst female respondents regarding unisex urinals. This indicates that this system may not be appropriate or better education campaigns are required. Additionally, research indicates that people are more likely to buy into an idea if they believe their actions have meaning (Patchen, 2006). Presenting information in a relatable way is likely the most realistic way these systems will gain traction.

\section{Design case results}

These results display a representation of the four hypothetical cases which UCT could implement when considering conservation of water, nutrient recovery and the installation of urine-diverting technologies. The following table displays a breakdown of the costs associated with each separate case. Graphical representations of the water usage per month of each system, as well as the capital, operational and cost recovery values can be found in Table 1 and Fig. 2A.

Additionally, it was found that approximately $6700 \mathrm{~kg}$ of fertilizer per annum could be produced from urine collected from urinals on Upper Campus, which is worth an estimated 10400 USD in sales. Case 3 constitutes the same cost recovery per annum that Case 4 does. The only difference is that this money is not recoverable by UCT, as can be seen in Fig. $2 \mathrm{~B}$. Instead, the recoverable money from fertilizer sales goes to the private company.

UCT requires roughly $3600 \mathrm{~kg}$ of fertilizer per year to treat the cricket and rugby fields (Makole, 2017). This costs approximately 2000 USD per annum. Case 4 presents an opportunity for monetary savings, as UCT could potentially use the urine-derived fertilizer for their sports fields instead of purchasing fertilizer from an external supplier, and sell the excess to recover the costs of producing the fertilizer.

\section{Design case data discussion}

Although a multitude of design assumptions were used to model each design case, these assumptions are based on previously recorded and documented measurements. Furthermore, each case investigated above presents logical reasons for why it should be considered as the preferred system.

In Case 1, the university is estimated to use $19 \mathrm{ML}$ of water per year on urinal flushing alone. This is roughly the amount of water needed to fill 8 Olympic-size swimming pools, assuming each swimming pool is $2.5 \mathrm{ML}$ in volume (Hoefs, 2017). This system does not include any form of resource recovery, as both liquid and solid waste is flushed into the sewer system to be treated at WWTPs. However, despite these negative aspects, this system represents a norm. Converting to a new system, which requires individuals to be more mindful of their bathroom routine (even though it may not change significantly), may cause confusion. In addition, the cost to retrofit a system needs to be considered even though water urinals are between 175 to $246 \%$ more expensive than waterless urinals. This could occur, despite efforts to educate the public. Further research pertaining to how people respond to alternate waste disposal technologies in practice in university settings, and their satisfaction levels in practice, are necessary to test the acceptance. In the current context, where the goal of the City
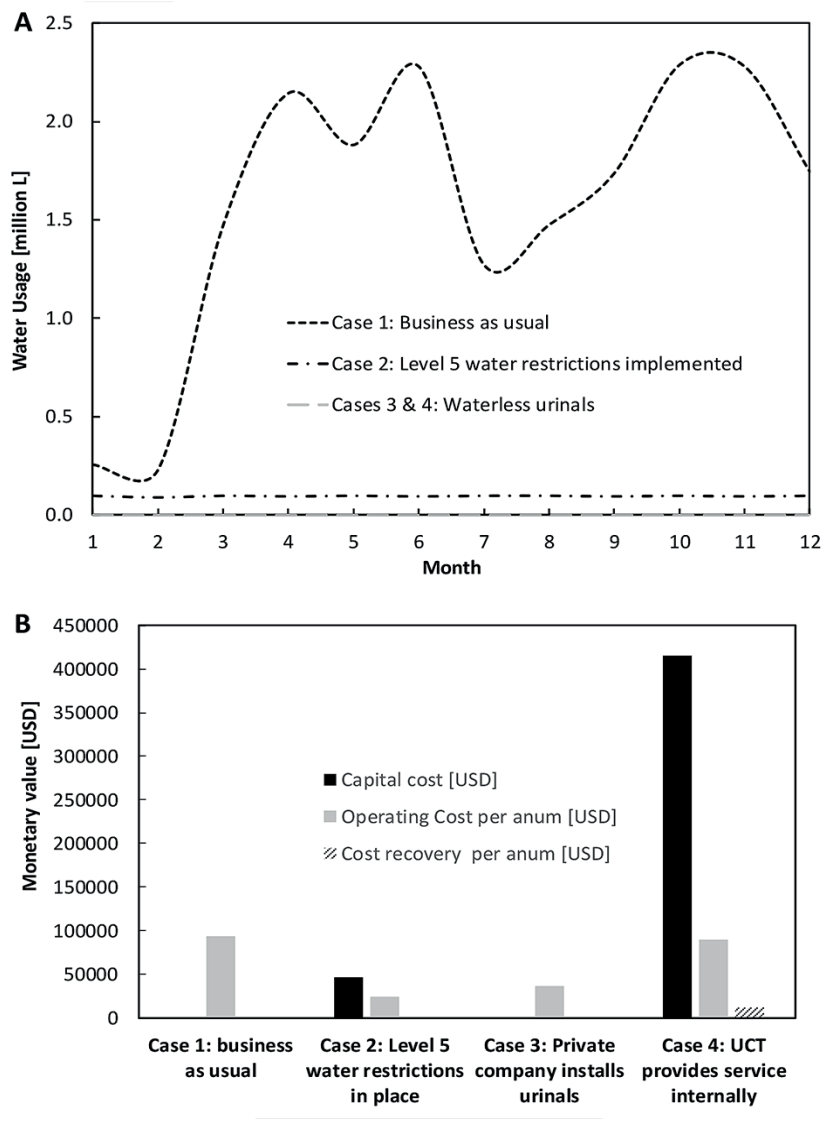

Figure 2

A: Monthly water usage throughout the university. B: Monetary valuation of each design case

\begin{tabular}{|l|c|c|c|c|c|}
\hline \multicolumn{7}{|c|}{ Tesign case evaluation } \\
\hline & $\begin{array}{c}\text { Capital } \\
\text { cost } \\
\text { (USD) }\end{array}$ & $\begin{array}{c}\text { Operating } \\
\text { cost per } \\
\text { annum (USD) }\end{array}$ & $\begin{array}{c}\text { Cost } \\
\text { recovery per } \\
\text { annum (USD) }\end{array}$ & $\begin{array}{c}\text { Water } \\
\text { usage per } \\
\text { annum (L) }\end{array}$ & $\begin{array}{c}\text { Urine } \\
\text { collected } \\
\text { per annum (L) }\end{array}$ \\
\hline Case 1: Business as usual & 0 & 100000 & 0 & 19000000 & 0 \\
\hline Case 2: Level 5 water restrictions in place & 50000 & 26000 & 0 & 1400000 & 0 \\
\hline Case 3: LiquidGold installs urinals & 0 & 39000 & 0 & 0 & 1010000 \\
\hline Case 4: UCT provides service internally & 420000 & 96000 & 124000 & 0 & 1010000 \\
\hline
\end{tabular}

Note: the water usage in Case 1 is split into 'term' and 'holiday' usage, yielding different amounts of flushes per day. Case 2 assumes each urinal is flushed 3 times every day, regardless of holiday or term time. 
of Cape Town is to decrease water usage wherever possible, the business-as-usual case becomes less attractive.

Case 2, however, presents a decrease in cost and water usage. This case does incorporate an initial capital cost but uses significantly less water than Case 1; this is due to the 3 flushes per urinal rule. This scenario could be made even more cost efficient by removing the timer flushers on each urinal. Instead, a cleaning staff member from each building could be tasked with manually flushing each urinal 3 times a day. This could be enforced by printing out posters advising users against flushing and pasting them on the walls above the urinals. This kind of water-saving drive has already been implemented in local malls in Cape Town. Despite having the lowest operating cost, this system does not incorporate any resource recovery and thus the nutrient burden is still placed on existing WWTPs. Comparatively, the water usage per year in Case 2 is enough to fill only half of an Olympic-size swimming pool.

Much of the appeal associated with Cases 3 and 4 is tied with the waterless nature of each design. Previously mentioned benefits include the decrease in the load being treated at WWTPs (which leads to a decrease in nitrogen and phosphorus in WWTP influent). Furthermore, these systems allow UCT to address the need for phosphorus conservation by actively promoting recycling of urine. However, from a monetary perspective, Case 4 yields a much greater overall cost due to the number of inputs that are required to be considered, based on this assessment.

Any decision regarding which case should be favoured ultimately will be based on what UCT as an establishment believes it should prioritize: resource recovery and water conservation or overall expenditure. If either one of these choices is a priority, Case 1 is eliminated from contention, as it requires the most amount of water. Similarly, Case 4 is eliminated as it requires the highest monetary input. This leaves Cases 2 and 3.

Initially, Case 3 is cheaper when compared to Case 2, due to the capital cost associated with Case 2 . After approximately 4 years of operation, Case 2 becomes the more economical option as is displayed in Fig. 3.

Case 3, however, involves urine recycling. Despite not being able to treat the urine and sell the fertilizer themselves, UCT could explore the option of negotiating discounts on the fertilizer with the private company for their sports fields and ornamental gardens. Although the investigation does not directly consider the environmental benefits of on-site urine collection and fertilizer production, the benefits could be significant. For example, the nutrient loads on existing wastewater treatment plants would be reduced. This would diminish the risk of unwanted nutrients entering the environment. In addition, it has been shown that implementing source separation could also make WWTPs net energy producers instead of consumers (Wilsenach and Van Loosdrecht, 2003).

\section{CONCLUSIONS}

Two separate analytical approaches were used to deduce the feasibility of installing waterless urinals at a public university in Cape Town, South Africa. It was found that $96 \%$ of respondents were willing to use a waterless urinal system to save water, and $79 \%$ of respondents were willing to eat food using phosphorus which was recycled from urine in fertilizers. Additionally, appealing to the proposed user base with solutions that they can personally contribute to is presumably the best approach if this system is to be

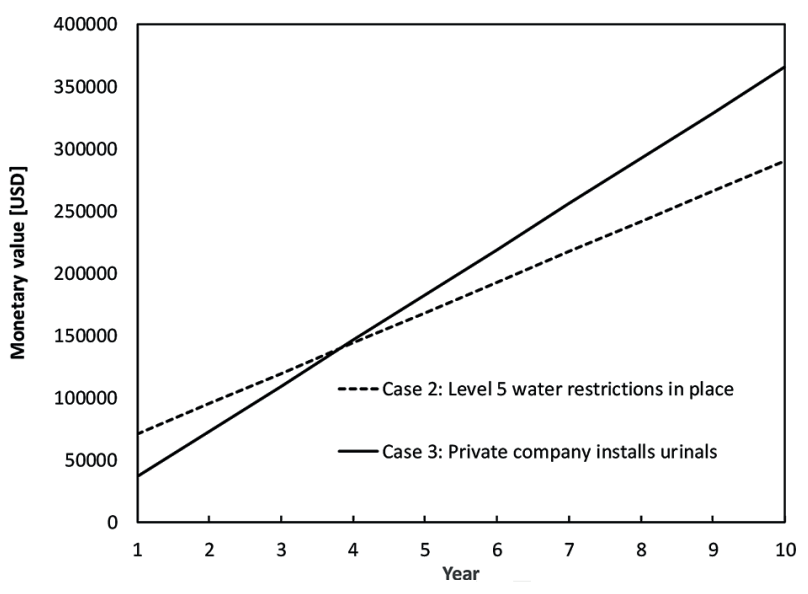

Figure 3

Overall cost comparison of Cases 2 and 3 over a 10-year period

considered for implementation. From the economical evaluation carried out, it is apparent that UCT could stand to benefit greatly from the installation of these systems. UCT uses approximately $19 \mathrm{ML}$ of potable water per year merely to flush urinals. This should be a cause for concern, knowing that the water usage within the university could decrease by simply reducing the number of urinal flushes, as is displayed from the design cases, as well as installing the water-efficient urinal models. Decreasing the number of flushes per day or contracting an external private company to install and maintain waterless urinals, while also collecting valuable nutrients on-site, would not only save water and recycle nutrients, but would also reduce overall expenditure. Additionally, approximately $6700 \mathrm{~kg} / \mathrm{yr}$ of fertilizer can potentially be manufactured from nutrient recovery urinals installed on Upper Campus. This could be sold for a 9 375 USD profit each year or it could be used to off-set the fertilizer demand of the university's sports fields.

With regards to the feasibility analysis conducted, Cases 2 and 3 provide strong evidence that they are more desirable than the current system. Case 2, based solely on the fact that it boasts the lowest overall cost over a 10 -year period, is the preferred option. In addition, it also saves approximately 18 ML of water per annum. However, there is no recycling of nutrients with Case 2. To remove the effects of scaling within pipes, in cases whereby urine collection is implemented, novel nutrient recovery urinals could be implemented. This would involve the use of a removable urinal container and thus the system would not be connected to the sewage line. This would allow for on-site fertilizer production while also saving water.

Although this study only focused on the implementation of waterless urinals and potential on-site nutrient recovery at UCT, the methodology and concepts could be implemented elsewhere, for example, in office blocks, malls and other commercial spaces, since the key infrastructure (urinals) would be the same. Simply reducing the number of urinal flushes could save significant amounts of water while implementing novel nutrient recovery schemes could help reduce unwanted nutrient loads into the environment. In addition, UCT should consider the operations and maintenance of waterless urinals as compared to existing urinal infrastructure while also considering the overall benefits, both in terms of sustainability and the environment. 


\section{ACKNOWLEDGEMENTS}

The authors would like to gratefully acknowledge the University of Cape Town for its financial support.

\section{REFERENCES}

ANDERSSON E (2015) Turning waste into value: using human urine to enrich soils for sustainable food production in Uganda. J. Clean. Prod. 96 290-298. https://doi.org/10.1016/j.jclepro.2014.01.070

ANDERSSON K, ROSEMARIN A, LAMIZANA B, KVARNSTRÖM E, MCCONVILLE J, SEIDU R, DICKIN S and TRIMMER C (2016) Sanitation, wastewater management and sustainability: from waste disposal to resource recovery. United Nations Environment Programme and Stockholm Environment Institute, Nairobi and Stockholm. URL: https://wedocs.unep.org/bitstream/ handle/20.500.11822/8465/-Sanitation,_wastewater_management and_sustainability_From_waste_disposal_to_resource_recovery2016sanitation wastewater management and sustainabilit. pdf? sequence $=2$ \&isAllowed $=$ y (Accessed 23 January 2019).

BARBOSA SG, PEIXOTO L, MEULMAN B, ALVES MM and PEREIRA MA (2016) A design of experiments to assess phosphorous removal and crystal properties in struvite precipitation of source separated urine using different $\mathrm{Mg}$ sources. Chem. Eng. J. 298 146-153. https://doi.org/10.1016/j. cej.2016.03.148

BLUME S and WINKER M (2011) Three years of operation of the urine diversion system at GTZ headquarters in Germany: user opinions and maintenance challenges. Water Sci. Technol. 64 (3) 579-586. https://doi.org/10.2166/wst.2011.530

BOHATCH T (2017) GroundUp: What's causing Cape Town's water crisis? URL: https://www.dailymaverick.co.za/article/2017-05-17groundup-whats-causing-cape-towns-water-crisis/\#.Wf_zKmiCzIU (Accessed 23 January 2019).

BOUGHTON WC (2009) Multi-year streamflow drought in eastern Australia. Austral. J. Water Resour. 13 (1) 31-42. https://doi.org/10. 1080/13241583.2009.11465358

CHARIAR M and SAKTHIVEL R (2009) Waterless Urinals: A Resource Book. IIT Delhi and Vigyan Vijay Foundation, Delhi, India.

CHISLOCK MF, DOSTER E, ZITOMER RA and WILSON AE (2013) Eutrophication: Causes, Consequences, and Controls in Aquatic Ecosystems. Nat. Educ. Knowl. 4 (4) 1-3.

COCT (City of Cape Town) (2016) Annexure 7 Tarrif Policies. In: Sanitation. URL: http://resource.capetown.gov.za/documentcentre/ Documents/Financial\%20documents/Annexure\%207\%20-\%20 Tariff\%20Policies.pdf (Accessed 23 January 2019).

CORDELL D, DRANGERT J-O and WHITE S (2009) The story of phosphorus: Global food security and food for thought. Glob. Environ. Change 19 (2) 292-305. https://doi.org/10.1016/j. gloenvcha.2008.10.009

DAI J, TANG W-T, ZHENG Y-S, MACKEY HR, CHUI HK, VAN LOOSDRECHT MCM and CHEN G-H (2014) An exploratory study on seawater-catalysed urine phosphorus recovery (SUPR). Water Res. 66 75-84.

ETTER B, UDERT KM and GOUNDEN T (2015) VUNA Final Report. VUNA, Dübendorf, Switzerland.URL: https://www.researchgate. net/publication/282849102_VUNA_Valorisation_of_Urine Nutrients_-_Final_Project_Report (Accessed 23 January 2019). https://doi.org/10.1016/j.watres.2014.08.008

FIELDING KS and ROIKO AH (2014) Providing information promotes greater public support for potable recycled water. Water Res. $\mathbf{6 1}$ 86-96. https://doi.org/10.1016/j.watres.2014.05.002

FLANAGAN CP and RANDALL DG (2018) Development of a novel nutrient recovery urinal for on-site fertilizer production. $J$. Environ. Chem. Eng. 6 (5) 6344-6350. https://doi.org/10.1016/j. jece.2018.09.060

GENTWORKS (2019) Gentworks Low Flush Urinal Cistern Timer (1 to 15 hour). URL: http://www.gentworks.co.uk/gentworks-low-flush. html (Accessed 23 January 2019).

HERMAN O (2017) Personal communication, 11 October 2017. Mr Orion Herman, LiquidGold CEO \& Founder, 292 Surrey Ave, Johannesburg 2194.
HOEFS J (2017) Measurement of an olympic size swimming pool. URL: https://www.livestrong.com/article/350103-measurementsfor-an-olympic-size-swimming-pool/ (Accessed 23 January 2019).

LAMICHHANE KM and BABCOCK RW (2013) Survey of attitudes and perceptions of urine-diverting toilets and human waste recycling in Hawaii. Sci. Total Environ. 443 749-756. https://doi. org/10.1016/j.scitotenv.2012.11.039

LIENERT J, BURKI T and ESCHER BI (2007) Reducing micropollutants with source control: substance flow analysis of 212 pharmaceuticals in faeces and urine. Water Sci. Technol. 56 (5) 87-96. https://doi.org/10.2166/wst.2007.560

LIENERT J and LARSEN TA (2010) High acceptance of urine source separation in seven European countries: a review. Environ. Sci. Technol. 44 (2) 556-566. https://doi.org/10.1021/es9028765

MAKOLE K (2017) Personal communication, 8 September 2017. Mr Karabo Makole, University of Cape Town student, Rondebosch, Cape Town 7700 .

MEYER G, FROSSARD E, MÄDER P, NANZER S, RANDALL DG, UDERT KM and OBERSON A (2018) Water soluble phosphate fertilizers for crops grown in calcareous soils - an outdated paradigm for recycled phosphorus fertilizers? Plant Soil 424 (1) 367-388. https://doi.org/10.1007/s11104-017-3545-x

MUNCH E and WINKER M (2011) Technology review of urine diversion components. Gesellschaft für Internationale Zusammenarbeit (GIZ) GmbH, Eschborn, Germany. URL: https://www.susana.org/en/knowledge-hub/resources-andpublications/library/details/875 (Accessed 23 January 2019). ODENDAAL C (2017) Personal communication, 18 August 2017. Mr Chr isto Odendaal, University of Cape Town Director Maintenance and Operations, 95 Main Road, Mowbray 7700.

OLIVIER D (2017) Cape Town water crisis: 7 myths that must be bust. URL: https://theconversation.com/cape-town-water-crisis7-myths-that-must-be-bust-86582 (Accessed 23 January 2019).

PATCHEN M (2006) Public attitudes and behavior about climate change: What shapes them and how to influence them. Purdue Climate Change Research Center. 23-30. URL: https://www. columban.jp/upload_files/data/EE0063_AttitudeChange.pdf (Accessed 23 January 2019).

RANDALL DG, KRÄHENBÜHL M, KÖPPING I, LARSEN TA and UDERT KM (2016) A novel approach for stabilizing fresh urine by calcium hydroxide addition. Water Res. 95 361-369. https:// doi.org/10.1016/j.watres.2016.03.007

RANDALL DG and NAIDOO V (2018) Urine: The liquid gold of wastewater. J. Environ. Chem. Eng. 6 (2) 2627-2635. https://doi. org/10.1016/j.jece.2018.04.012

RICHERT AG, R. JONSSON, H. STENSTROM, T. DAGERSKOG. (2010) Practical Guidance on the Use of Urine in Crop Production. Stockholm Environment Institute, Stockholm.

ROSSI L, LIENERT J and LARSEN TA (2009) Real-life efficiency of urine source separation. J. Environ. Manage. 90 (5) 1909-1917. https://doi.org/10.1016/j.jenvman.2009.01.006

SHARVELL S (2016) A new strategy for drought-stressed cities: graywater recycling. URL: https://theconversation.com/a-newstrategy-for-drought-stressed-cities-graywater-recycling-56564 (Accessed 20 Nov 2016)

SHRAIM A, DIAB A, ALSUHAIMI A, NIAZY E, METWALLY M, AMAD M, SIOUD S and DAWOUD A (2017) Analysis of some pharmaceuticals in municipal wastewater of Almadinah Almunawarah. Arab. J. Chem. 10 S719-S729. https://doi. org/10.1016/j.arabjc.2012.11.014

SIKOSANA M, RANDALL DG, PETRIE DJ, OELOFSE M, RUSSO V and VON BLOTTNITZ H (2017) A technological and economic exploration of phosphate recovery from centralised sewage treatment in a transitioning economy context. Water $S A 43$ (2) 343-353. https://doi.org/10.4314/wsa.v43i2.17

SMITH MD, STEAR RM and PARR J (1996) Seawater for nonpotable uses. In: $22^{\text {nd }}$ Water, Engineering and Development Centre Conference, 9-13 September 1996], New Delhi, India. 241-243.

UCT (University of Cape Town) (2019) Students come to UCT from all over Africa and the world. URL: http://www.students.uct. ac.za/ (Accessed 23 January 2019). 
UDERT KM (in press) Phosphorus as a resource. In: Shaum CS (ed) Phosphorus: Polluter and Resource of the Future - Removal and Recovery from Wastewater. IWA Publishing, London.

VON MÜNCH E and DAHM P (2009) Waterless urinals - a proposal to save water and recover urine nutrients in Africa. In: $34^{\text {th }} W E D C$ International Conference, 18-22 May 2009, Addis Ababa, Ethiopia.

WILLIAMS AP, SEAGER R, ABATZOGLOU JT, COOK BI,

SMERDON JE and COOK ER (2015) Contribution of anthropogenic warming to California drought during
2012-2014. Geophys. Res. Lett. 42 (16) 6819-6828. https://doi. org/10.1002/2015GL064924

WILSENACH J and VAN LOOSDRECHT M (2003) Impact of separate urine collection on wastewater treatment systems. Water Sci. Technol. 48 (1) 103-110. https://doi.org/10.2166/wst.2003.0027

ZHANG J, GIANNIS A, CHANG VW, NG BJ and WANG JY (2013) Adaptation of urine source separation in tropical cities: Process optimization and odor mitigation. J. Air Waste Manage. Assoc. 63 (4) 472-481. https://doi.org/10.1080/10962247.2013.763306 


\section{APPENDIX}

TABLE A1

Questions included in the online survey of the investigation as well as the answer options available.

\begin{tabular}{|c|c|}
\hline Question no. & Questions \\
\hline 1 & $\begin{array}{l}\text { What is your gender? } \\
\square \text { Male } \square \text { Female }\end{array}$ \\
\hline 2 & $\begin{array}{l}\text { What is your age range? } \\
\square 18-22 \quad \square 23-30 \quad \square 31-40 \quad \square 40 \text { and above }\end{array}$ \\
\hline 3 & $\begin{array}{l}\text { What faculty do you belong to? } \\
\square \text { Commerce } \square \text { Engineering and Built Environment } \square \text { Health Science } \\
\square \text { Humanities } \square \text { Law } \square \text { School of Education } \square \text { Science }\end{array}$ \\
\hline 4 & $\begin{array}{l}\text { What is your position at the University of Cape Town } \\
\square \text { Student } \square \text { Staff }\end{array}$ \\
\hline 5 & $\begin{array}{l}\text { Before this survey, had you heard of waterless urinals and source-separating toilets? } \\
\square \text { Yes } \square \text { No }\end{array}$ \\
\hline 6 & $\begin{array}{l}\text { Would you be willing to use a waterless urinal and/ or source-separating toilet? } \\
\square \text { Yes } \square \text { No }\end{array}$ \\
\hline 7 & $\begin{array}{l}\text { If not, why not? } \\
\square \text { Sanitation Concerns } \quad \square \text { Aiming at separate bowls is inconvenient } \\
\square \text { System maintenance concerns } \square \text { Religious reasons } \\
\square \text { Other, personal reasons } \square \text { Not applicable }\end{array}$ \\
\hline 8 & $\begin{array}{l}\text { Would you use a waterless urinal or source-separating toilet, knowing it could save water during times of } \\
\text { severe water restrictions in Cape Town? } \\
\square \text { Yes } \square \text { No }\end{array}$ \\
\hline 9 & $\begin{array}{l}\text { Would you be willing to use a unisex waterless urinal, knowing it could save water during times of severe } \\
\text { water restrictions in Cape Town? } \\
\square \text { Yes } \square \text { No }\end{array}$ \\
\hline 10 & $\begin{array}{l}\text { Do you think it is possible that source-separating toilets will be utilized correctly by users in a University } \\
\text { environment? } \\
\square \text { Yes } \square \text { No }\end{array}$ \\
\hline 11 & $\begin{array}{l}\text { Before this survey, were you aware that the world is running out of phosphorus, an essential nutrient used to } \\
\text { grow food? } \\
\square \text { Yes } \square \text { No }\end{array}$ \\
\hline 12 & $\begin{array}{l}\text { Would you recycle phosphorus to grow food, if it were possible? } \\
\square \text { Yes } \square \text { No }\end{array}$ \\
\hline 13 & $\begin{array}{l}\text { Moreover, what if that phosphorus originated from your own or someone else's urine? Would you be willing } \\
\text { to eat food grown using this recycled phosphorus as fertilizer? } \\
\square \text { Yes } \square \text { No }\end{array}$ \\
\hline 14 & $\begin{array}{l}\text { If not, why not? } \\
\square \text { Religious reasons } \quad \square \text { Health concerns } \quad \square \text { Other, personal reasons } \\
\square \text { Not applicable }\end{array}$ \\
\hline
\end{tabular}




\begin{tabular}{|c|c|c|c|}
\hline \multicolumn{4}{|c|}{$\begin{array}{c}\text { TABLE A2 } \\
\text { Design assumptions used for each design case }\end{array}$} \\
\hline Description & Unit & Value & Reference \\
\hline Total UCT population & People & 34000 & UCT (2019) \\
\hline Total Upper Campus population & People & 16500 & Assumed from an equal faculty split \\
\hline Male population on Upper Campus population & $\%$ & 48 & Assumed \\
\hline Staff population on Upper Campus population & $\%$ & 13.5 & Assumed \\
\hline Urinals on Upper Campus & Urinals & 260 & (Odendaal, 2017) \\
\hline Water used per flush & $\mathrm{L}$ & 4 & (Von Münch and Dahm, 2009) \\
\hline Number of term days per year & Days & 237 & Assumed \\
\hline Number of holiday days per year & Days & 128 & Assumed \\
\hline Urination frequency on per person per day & Toilet visits & 5 & (Rossi et al., 2009) \\
\hline Urination frequency on campus per person per day & Toilet visits & 3 & Assumed \\
\hline Urine produced per person per day & $\mathrm{L}$ & 1.15 & (Richert, 2010) \\
\hline Urine Produced per urinal usage per person & $\mathrm{L}$ & 0.23 & Assumed from urination frequency \\
\hline Struvite produced per L & $\mathrm{kg}$ & 0.006 & Assumed \\
\hline Time spent cleaning one urinal & s & 120 & Assumed \\
\hline
\end{tabular}

\begin{tabular}{|l|c|c|c|}
\hline \multicolumn{4}{|c|}{ TABLE A3 } \\
Monetary value assumptions for each design case based on a USD - ZAR exchange rate of 12:1. \\
\hline Description & Unit & Value & Source \\
\hline Magnesium per L of urine & USD & 0.01 & (Herman, 2017) \\
\hline Selling price of struvite per kg & USD & 1.5 & (Herman, 2017) \\
\hline Water per kL & USD & 2.5 & (CoCT, 2016) \\
\hline Sewage services per kL & USD & 2 & (CoCT, 2016) \\
\hline Staff salary per hour & USD & 5 & Assumed \\
\hline Cleaning products per urinal per day & USD/ 750 mL bleach bottle & 2.2 & Assumed \\
\hline Treatment plant annual operating cost & USD/ kL treated & 75000 & (Sikosana et al., 2016) \\
\hline Treatment plant capital costs & USD/ kL treated & 13000 & (Sikosana et al., 2016) \\
\hline Timer flushing device & USD per unit & 195 & (Gentworks, 2017) \\
\hline Waterless urinal installation & USD per unit & 120 & Assumed \\
\hline
\end{tabular}




\begin{tabular}{|l|l|c|c|l|}
\hline \multicolumn{5}{|c|}{ TABLE A4 } \\
\hline Parameter & Groups compared & $\chi^{2}$ & \multicolumn{1}{|c|}{$P$-value } & Results \\
\hline Willingness to use urine diverting technology & Males and females & 1.06 & 0.301 & Fail to reject $H_{0}$ \\
\hline Willingness to use urine diverting technology & $\begin{array}{l}\text { EBE faculty and Humanities } \\
\text { faculty }\end{array}$ & 0.15 & 0.69 & Fail to reject $H_{0}$ \\
\hline $\begin{array}{l}\text { Willingness to eat food grown using urine } \\
\text { derived fertilizer }\end{array}$ & Males and females & 5.81 & 0.015 & Reject $H_{0}$ \\
\hline $\begin{array}{l}\text { Willingness to eat food grown using urine } \\
\text { derived fertilizer }\end{array}$ & $\begin{array}{l}\text { EBE faculty and Humanities } \\
\text { faculty }\end{array}$ & 4.56 & 0.032 & Reject $H_{0}$ \\
\hline Willingness to use unisex urinals & Males and females & 47.89 & $4.51 \times 10^{-12}$ & Reject $H_{0}$ \\
\hline Faith in facility maintenance by user base & Staff and students & 4.43 & 0.035 & Reject $H_{0}$ \\
\hline
\end{tabular}

